\title{
CS-15 - Mejora en la capacidad de redacción científica en los investigadores de la Universidad de San Carlos de Guatemala
}

\author{
Improvement in the capacity of scientific writing in the researchers of the \\ University of San Carlos de Guatemala
}

\author{
Julio R. Salazar, Andrea E. Rodas-Moran*, Saúl Guerra, Federico Nave, Gerardo Arroyo, \\ Armando Cáceres
}

Dirección General de Investigación, Universidad de San Carlos de Guatemala

*Autor a quien se dirige la correspondencia: cts@digi.usac.edu.gt

\section{Resumen}

$\mathrm{D}$ entro del proceso de divulgación de resultados de investigación, las publicaciones científicas indexadas toman un rol importante debido a la visibilidad y calidad editorial. La Universidad de San Carlos de Guatemala, por medio de la Dirección General de Investigación, ha realizado acciones para fomentar en el país, una cultura de publicación. Dentro de estas acciones se encuentra el diseño de un curso de redacción científica para los investigadores con fondos universitarios. Este curso se encuentra dividido en tres sesiones: (1) herramientas para la redacción científica, (2) estructura de un manuscrito, (3) edición y revisión. Para la evaluación de este curso, se utilizó los manuscritos presentados a consideración editorial, a la revista Ciencia, Tecnología y Salud, en 2015 ( $\sin$ un curso estructurado) y 2016 (con el curso estructurado). Se observó un aumento en el índice de ingreso a la revista. Este curso proporcionó habilidades de redacción científica y capacidades profesionales, aumentando la visibilidad de las investigaciones del país.

Palabras claves: Competencias lingüísticas, redacción académica, edición científica, visibilidad

\section{Abstract}

$\mathrm{W}$

ithin the process of dissemination of research results, indexed scientific publications take an important role due to the visibility and editorial quality. The Universidad de San Carlos de Guatemala, through of Dirección General de Investigación, has carried out actions to promote the country, a culture of publication. Among these actions is the design of a scientific writing course for researchers. This course is divided into three sessions: (1) tools for scientific writing, (2) structure of a manuscript, (3) editing and revision. For the evaluation of this course, an editorial review was made to the journal Ciencia, Tecnología y Salud, in 2015 (without a structured course) and 2016 (with a structured course). It has been increased in number of manuscript receive. This course provided scientific writing skills and professional skills, increasing the visibility of the country's research.

Key words: Linguistic competences, academic writing, scientific edition, visibility 